\title{
HUBUNGAN KADAR LEUKOSIT, MONOSIT, DAN PROKALSITONIN DENGAN KEJADIAN INFEKSI DAN LUARAN FUNGSIONAL PADA STROKE AKUT
}

\author{
ASSOCIATION OF LEUKOCYTE, MONOCYTE, AND PROCALCITONIN LEVEL WITH \\ INFECTION AND FUNCTIONAL OUTCOME IN ACUTE STROKE \\ Rivita Putri Nasari, * Aldy Safruddin Rambe, * Aida Fithrie*
}

\begin{abstract}
Introduction: Infection is a common complication in the acute of stroke. Stroke can lead to immediate stage of immunosuppression, increasing the risk of infection.

Aims: To evaluate the relationship levels of leukocyte, monocyte, and procalcitonin with infection and functional outcome in acute stroke.

Methods: A cross-sectional study of acute stroke patients in RSUP Dr. Adam Malik neurology ward, Medan, from June to October 2015. Diagnosis was made by clinical findings and brain CT scan. Patients with previous stroke, treated as having infection or already treated by antibiotics before admission were excluded from this study. All subjects examined for the levels of leukocytes, monocytes, and procalcitonin and observed the infection and assessed functional outcome (mRS) on day 14 of onset.

Results: There were 50 subjects with age mean 57.2 (40-73) years old, mostly male (54\%) and had ischemic stroke (82\%). Leukocytes and procalcitonin level has positive association with infection in acute stroke significantly. Subjects whom had normal leucocyte at baseline tend not to developed infection 3.69 times compared to whom had high leucocyte at baseline. Similar with PCT, subjects with normal level of PCT at base tend not to developed infection 16.9 times compared to subject with high level of PCT at baseline. High level of leucocyte also related with low functional outcome, significantly.

Discussions: There were positive associated between leukocytes and procalcitonin levels with risk of infection, and negative associated between leukocytes levels with functional outcome in acute stroke.
\end{abstract}

Keywords: Infection, leukocytes, monocytes, outcome, procalcitonin

\section{ABSTRAK}

Pendahuluan: Infeksi merupakan komplikasi yang umum pada stroke akut. Stroke dapat menyebabkan immunosupresi dalam tahap awal, sehingga dapat meningkatkan risiko infeksi.

Tujuan: Untuk mengetahui hubungan kadar leukosit, monosit, dan prokalsitonin (PCT) dengan kejadian infeksi dan luaran fungsional pada stroke akut.

Metode: Penelitian potong lintang terhadap pasien stroke akut yang dirawat di Ruang Rawat Inap Terpadu Departemen Neurologi RSUP Haji Adam Malik, Medan, pada bulan Juni 2015 hingga Oktober 2016. Diagnosis ditegakkan berdasarkan gejala klinis dan pemeriksaan CT scan kepala. Kriteria eksklusi adalah mengalami infeksi atau sudah menggunakan antibiotik pada saat masuk rumah sakit (RS) serta mengalami stroke berulang. Subjek dilakukan pemeriksaan kadar leukosit, monosit, dan prokalsitonin, lalu diamati ada tidaknya kejadian infeksi selama perawatan dan penilaian mRS pada hari ke-empat belas awitan.

Hasil: Didapatkan 50 subjek dengan rerata usia 57,2 (40-73) tahun, mayoritas laki-laki (54\%) dan mengalami stroke iskemik (82\%). Terdapat hubungan yang signifikan antara kadar leukosit dan prokalsitonin dengan kejadian infeksi pada stroke akut. Subjek dengan kadar leukosit awal yang normal lebih cenderung untuk tidak mengalami kejadian infeksi sebesar 3,69 kali dibandingkan yang leukositnya tinggi. Demikian pula kadar PCT yang normal di awal cenderung untuk tidak mengalami kejadian infeksi sebesar 16,9 kali dibandingkan subjek dengan PCT tinggi. Kadar leukosit yang tinggi juga berhubungan dengan luaran fungsional yang buruk secara bermakna.

Diskusi: Terdapat hubungan positif yang signifikan kadar leukosit dan prokalsitonin dengan kejadian infeksi serta hubungan negatif yang signifikan kadar leukosit dengan luaran fungsional pada stroke akut.

Kata kunci: Infeksi, leukosit, luaran, monosit, prokalsitonin

*Departemen Neurologi FK Universitas Sumatera Utara/RSUP Haji Adam Malik, Medan. Korespondensi: rivita_dvd@yahoo.com.

\section{PENDAHULUAN}

Stroke adalah penyebab utama kematian dan kecacatan jangka panjang di seluruh dunia. Sebuah penelitian menunjukkan bahwa jumlah leukosit adalah prediksi stroke iskemik pertama setelah disesuaikan dengan faktor risiko vaskular. Namun, 
tidak ada konsensus tentang hubungan antara jumlah leukosit dan prognosis infark serebral setelah onset. Beberapa studi telah menemukan bahwa peningkatan jumlah leukosit di hari pertama stroke iskemik akut adalah faktor prognosis perkembangan penyakit dan jumlah leukosit merupakan faktor prediktif kematian yang penting di rumah sakit (RS). ${ }^{1}$

Peran aktivasi sistem kekebalan tubuh bawaan dan adaptif pada stroke semakin dikenal, tetapi masih diperlukan penelitian lebih lanjut. ${ }^{2}$ Monosit merupakan fokus perhatian pada stroke, oleh karena monosit merupakan sel utama pada sistem imun bawaan yang juga dapat memengaruhi sistem imun yang didapat. ${ }^{3}$

Monosit dapat mencapai sistem saraf pusat pada 4 jam pertama dari onset stroke iskemik akut, karena pada stroke terjadi injuri serebral dan selain itu juga terjadi kerusakan sawar darah otak, meskipun infiltrasi maksimal terjadi setelah 7 hari. Dalam uji eksperimental pada stroke iskemik, monosit dapat mencetuskan terjadinya inflamasi, tetapi monosit juga dapat berkonstribusi pada resolusi inflamasi. ${ }^{3}$ Pada pasien dengan stroke akut, ada peningkatan yang signifikan dalam jumlah monosit yang beredar, dan kenaikan ini sangat mencolok pada pasien yang mengalami stroke terkait infeksi. Oleh karena itu, pasien stroke mudah terjadi infeksi karena imunodepresi. ${ }^{4}$

Stroke juga dapat menginduksi deaktivasi monosit, yang ditandai dengan penurunan ekspresi dari human leukocyte antigen-DR (HLA-DR) dan gangguan dari produksi sitokin proinflamasi pada stimulasi dengan lipopolisakarida. Ekspresi yang berlebihan dari tool-like receptors-4 (TLR4) pada monosit dari pasien dengan stroke akut baru-baru ini dikaitkan dengan prognosis yang buruk. ${ }^{3}$

Prokalsitonin (procalcitonin/PCT) merupakan penanda yang umum digunakan dan mempunyai akurasi diagnostik untuk berbagai infeksi, bahkan sebagai baku emas untuk diagnosis klinis bakteri. ${ }^{5}$ Menurut Su dkk kadar PCT dan c-reactive protein (CRP) berperan dalam diagnosis sepsis yang dini pada pasien yang dirawat di intensive care unit (ICU) dengan sensitivitas masing-masing $72,9 \%$ dan $67,9 \%{ }^{6}$
Tabel 1. Karakteristik Subjek Penelitian $(n=50)$

\begin{tabular}{|c|c|}
\hline Karakteristik & n $(\%)$ \\
\hline Usia (rerata+SD)(tahun) & $57,2 \pm 7,7$ \\
\hline \multicolumn{2}{|l|}{ Jenis Kelamin } \\
\hline - Laki-laki & $27(54)$ \\
\hline - Perempuan & $23(46)$ \\
\hline \multicolumn{2}{|l|}{ Suku } \\
\hline - Batak & $23(46)$ \\
\hline - Jawa & $17(34)$ \\
\hline - Karo & $8(16)$ \\
\hline - Aceh & $2(4)$ \\
\hline \multicolumn{2}{|l|}{ Pekerjaan } \\
\hline - Pegawai Negeri Sipil & $16(32)$ \\
\hline - Ibu Rumah Tangga & $16(32)$ \\
\hline - Wiraswasta & $11(22)$ \\
\hline - Petani & 7 \\
\hline \multicolumn{2}{|l|}{ Pendidikan } \\
\hline - SD-SMP & $17(34 \%)$ \\
\hline - SMA-Sarjana & $33(66 \%)$ \\
\hline \multicolumn{2}{|l|}{ Jenis Stroke } \\
\hline - Iskemik & $41(82)$ \\
\hline - Hemoragik & $9(18)$ \\
\hline Leukosit $/ \mathbf{m m}^{3}$ (rerata) & $11,256 \pm 2,677$ \\
\hline - Infeksi & $11,718 \pm 2,704$ \\
\hline - Tidak infeksi & $10,668 \pm 2,584$ \\
\hline - Luaran baik & $9,757 \pm 2,431$ \\
\hline - Luaran buruk & $12,255 \pm 2,378$ \\
\hline Monosit \% (rerata) & $9,01 \pm 9,8$ \\
\hline - Infeksi & $7,54 \pm 1,84$ \\
\hline - Tidak infeksi & $10,87 \pm 14,6$ \\
\hline - Luaran baik & $10,86 \pm 15,39$ \\
\hline - Luaran buruk & $7,77 \pm 2,04$ \\
\hline Prokalsitonin ng/mL (rerata) & $0,43 \pm 0,79$ \\
\hline - Infeksi & $0,64 \pm 0,98$ \\
\hline - Tidak infeksi & $0,16 \pm 0,3$ \\
\hline - Luaran baik & $0,18 \pm 0,23$ \\
\hline - Luaran buruk & $0,59 \pm 0,98$ \\
\hline \multicolumn{2}{|l|}{ Infeksi } \\
\hline - $\mathrm{Ya}$ & $28(56)$ \\
\hline - Tidak & $22(44)$ \\
\hline \multicolumn{2}{|l|}{ Luaran } \\
\hline - Baik & $21(42)$ \\
\hline - Buruk & $29(58)$ \\
\hline
\end{tabular}

Fluri dkk menemukan bahwa leukosit, CRP, kopeptin dan PCT merupakan prediktor independen pada infeksi pneumonia, dan infeksi saluran kemih yang berkembang paling tidak 24 jam setelah pengukuran. ${ }^{7}$ Infeksi merupakan komplikasi yang umum pada fase akut setelah stroke. Tingkat infeksi dilaporkan setelah stroke sangat bervariasi, mulai dari $5-65 \%{ }^{8}$ 


\section{TUJUAN}

Untuk mengetahui hubungan antara kadar leukosit, monosit, dan prokalsitonin dengan risiko kejadian infeksi dan luaran fungsional pada stroke akut.

\section{METODE}

Penelitian ini bersifat deskriptif analitik secara potong lintang terhadap penderita stroke akut yang dirawat di Ruang Rawat Inap Terpadu Departemen Neurologi RSUP Haji Adam Malik, Medan, pada bulan Juni 2015 hingga Oktober 2016. Diagnosis ditegakkan berdasarkan gejala klinis dan pemeriksaan CT scan kepala. Kriteria eksklusi adalah mengalami infeksi atau sudah menggunakan antibiotik pada saat masuk rumah sakit (RS) serta mengalami stroke berulang. Selanjutnya subjek dilakukan pemeriksaan kadar leukosit, monosit, dan prokalsitonin pada saat masuk RS, lalu diamati ada tidaknya kejadian infeksi selama perawatan dan dilakukan penilaian modified Rating Scale (mRS) pada hari ke-empat belas awitan. Kuesioner ini merupakan skala rating luaran global dengan nilai dari 0 (tidak ada gangguan) hingga dengan risiko kejadian infeksi dan luaran fungsional menggunakan uji Somers'd. Untuk mengetahui risiko leukosit, monosit, dan prokalsitonin dengan terjadinya infeksi, digunakan uji regresi logistik.

\section{HASIL}

Didapatkan 50 subjek (Tabel 1) dengan rerata usia 57,2 (40-73) tahun, mayoritas laki-laki (54\%), suku Batak (46\%), dan pendidikan Sekolah Menengah Atas (SMA) (54\%). Jenis stroke yang paling banyak adalah stroke iskemik (82\%), rerata kadar leukosit $11.256 \pm 2.677 / \mathrm{mm}^{3}$, rerata kadar monosit $9,01 \pm 9,8 \%$, dan rerata kadar prokalsitonin $0,43 \pm 0,79 \mathrm{ng} / \mathrm{mL}$. Sebanyak 56\% subjek mengalami infeksi dan $42 \%$ memiliki luaran fungsional yang baik.

Pada subjek yang mengalami infeksi, didapatkan rerata kadar leukosit $11.718 \pm 2.704 / \mathrm{mm}^{3}$; rerata kadar monosit $7,54 \pm 1,84 \%$, dan rerata kadar prokalsitonin $0,64 \pm 0,98 \mathrm{ng} / \mathrm{mL}$. Adapun subjek yang memiliki luaran baik menunjukkan rerata kadar leukosit $9,757 \pm 2,431 / \mathrm{mm}^{3}$, rerata kadar monosit $10,88 \pm 15,39 \%$, dan rerata kadar prokalsitonin $0,18 \pm 0,23 \mathrm{ng} / \mathrm{mL}$ (Tabel 1).

Tabel 2. Hubungan antara Kadar Leukosit, Monosit, dan Prokalsitonin dengan Kejadian Infeksi (n=50)

\begin{tabular}{|c|c|c|c|c|c|c|}
\hline \multirow[b]{2}{*}{ Variabel } & \multicolumn{2}{|c|}{ Infeksi } & \multirow[b]{2}{*}{$\mathbf{r}$} & \multirow[b]{2}{*}{$\mathbf{p}^{*}$} & \multirow[b]{2}{*}{ RO } & \multirow[b]{2}{*}{ IK 95\% } \\
\hline & $\begin{array}{c}\text { Ya } \\
\text { n (\%) }\end{array}$ & $\begin{array}{c}\text { Tidak } \\
\text { n }(\%)\end{array}$ & & & & \\
\hline $\begin{array}{l}\text { Leukosit } \\
\text { - Normal } \\
\text { - } \quad \text { Tinggi }\end{array}$ & $\begin{array}{c}9(39,1 \%) \\
19(70,4 \%)\end{array}$ & $\begin{array}{c}14(60,9 \%) \\
8(29,6 \%)\end{array}$ & 0,315 & 0,02 & 3,694 & $(1,139-11,978)$ \\
\hline $\begin{array}{l}\text { Monosit } \\
\text { - Normal } \\
\text { - } \quad \text { Tinggi }\end{array}$ & $\begin{array}{l}12(46,2 \%) \\
16(66,7 \%)\end{array}$ & $\begin{array}{c}14(53,8 \%) \\
8(33,3 \%)\end{array}$ & 0,208 & 0,135 & 2,333 & $(0,741-7,344)$ \\
\hline $\begin{array}{l}\text { Prokalsitonin } \\
\text { - Normal } \\
\text { - } \quad \text { Tinggi }\end{array}$ & $\begin{array}{c}6(25,0 \%) \\
22(84,6 \%)\end{array}$ & $\begin{array}{c}18(75,0 \%) \\
4(15,4 \%)\end{array}$ & 0,604 & 0,000 & 16,5 & $(4,028-67,596)$ \\
\hline
\end{tabular}

*Uji regresi logistik; RO: rasio Odds; IK: interval kepercayaan.

5 (hanya terbaring ditempat tidur, inkontinensia, membutuhkan perawatan dan perhatian menetap) dan 6 (luaran fatal). Skor 1-3 dikelompokkan sebagai luaran baik sedangkan 4-6 dikelompokkan sebagai luaran jelek. Infeksi didiagnosis dengan adanya demam (suhu $\geq 38^{\circ} \mathrm{C}$ ) dan peningkatan penanda nonspesifik inflamasi sistemik (leukosit $\geq 11.000$ / $\mathrm{mm}^{3}$, LED $>20 \mathrm{~mm} / \mathrm{jam}$, dan CRP $\geq 10 \mathrm{mg} / \mathrm{L}$ ).

Data hasil penelitian dianalisis secara statistik menggunakan program SPSS. Untuk melihat hubungan kadar leukosit, monosit, dan prokalsitonin
Tabel 2 menunjukkan adanya hubungan yang signifikan antara kadar leukosit dan prokalsitonin dengan kejadian infeksi pada stroke akut $(r=0,315$; $\mathrm{p}=0,020)$ dan $(\mathrm{r}=0,604 ; \mathrm{p}=0,000)$. Subjek dengan kadar leukosit awal yang normal lebih cenderung untuk tidak mengalami kejadian infeksi sebesar 3,69 kali dibandingkan yang leukositnya tinggi. Demikian pula kadar PCT yang normal di awal cenderung untuk tidak mengalami kejadian infeksi sebesar 16,9 kali dibandingkan subjek dengan PCT tinggi. Kadar leukosit yang tinggi juga berhubungan dengan luaran 
fungsional yang buruk secara bermakna $(\mathrm{r}=-0,685$ $\mathrm{p}=0,000$ ), seperti pada Tabel 3 .

Tabel 3. Hubungan antara Kadar Leukosit, Monosit, dan Prokalsitonin dengan Luaran Fungsional $(\mathrm{n}=50)$

\begin{tabular}{ccccc}
\hline \multirow{2}{*}{ Variabel } & $\begin{array}{c}\text { Baik } \\
\mathbf{n}(\%)\end{array}$ & $\begin{array}{c}\text { Buruk } \\
\mathbf{n}(\%)\end{array}$ & r & p* \\
\cline { 2 - 4 } $\begin{array}{c}\text { Leukosit } \\
\text { - Normal }\end{array}$ & $18(78,3 \%)$ & $5(21,7 \%)$ & & \\
- Tinggi & $3(11,1 \%)$ & $24(88,9 \%)$ & $-0,685$ & 0,000 \\
Monosit & & & & \\
- Normal & $14(53,8 \%)$ & $12(46,2 \%)$ & $-0,253$ & 0,067 \\
- Tinggi & $7(29,2 \%)$ & $17(70,8 \%)$ & & \\
Prokalsitonin & & & & \\
- Normal & $13(54,2 \%)$ & $11(45,8 \%)$ & $-0,240$ & 0,086 \\
- Tinggi & $8(30,8 \%)$ & $18(69,2 \%)$ & & \\
\hline
\end{tabular}

*Uji Somers'd.

Risiko terbesar terjadinya infeksi pada stroke akut yang secara statistik signifikan adalah pada variabel prokalsitonin (RO 0,022; IK 95\% 0,0020,205), dibandingkan leukosit (RO 0,073; IK 95\% 0,008-0,654) dan monosit (RO 1,174; IK 95\% 0,2445,644), seperti pada Tabel 4.

Tabel 4. Perbandingan Risiko antara Leukosit, Monosit, dan Prokalsitonin dengan Kejadian Infeksi $(\mathbf{n}=\mathbf{5 0})$

\begin{tabular}{lccc}
\hline Variabel & $\mathbf{p}^{*}$ & RO & IK 95\% \\
\hline Leukosit & 0,019 & 0,073 & $0,008-0,654$ \\
Monosit & 0,841 & 1,174 & $0,244-5,644$ \\
Prokalsitonin & 0,001 & 0,022 & $0,002-0,205$ \\
\hline
\end{tabular}

*Uji Multivariat Regresi Logistik; RO: rasio Odds; IK: interval kepercayaan.

\section{PEMBAHASAN}

Pada pasien dengan stroke iskemik akut dijumpai leukosit meningkat. Hal ini disebabkan oleh peningkatan ambilan leukosit pada area infark yang menginfiltrasi daerah dengan defek perfusi. ${ }^{9}$ Pada penelitian ini didapatkan bahwa kadar leukosit yang tinggi secara bermakna pada subjek penelitian memiliki hubungan dengan kejadian infeksi dibandingkan dengan subjek yang memiliki kadar leukosit yang normal pada saat masuk RS. Hal ini sejalan dengan Fluri dkk menemukan dari 383 pasien stroke, sebanyak $17,2 \%$ mengalami infeksi di dalam 5 hari pascastroke. Leukosit, CRP, kopeptin, dan PCT merupakan prediktor independen pada infeksi pneumonia dan infeksi saluran kemih yang berkembang dalam 24 jam setelah pengukuran. Dari analisis univariat, kadar leukosit yang tinggi pada saat masuk RS berisiko 3,35 kali menyebabkan kejadian infeksi (IK 95\% 2,14-5,23). ${ }^{7}$ Furlan dkk mendapatkan pasien dengan kadar leukosit tinggi pada saat masuk RS lebih rentan terhadap infeksi saluran kemih atau pernapasan dan sepsis pada harihari berikutnya setelah stroke. Disregulasi respons imun pada stroke akut telah dilaporkan berperan sebagai faktor predisposisi penting untuk terjadinya infeksi pascastroke. ${ }^{10}$

Penelitian ini menunjukkan bahwa terdapat hubungan yang tidak bermakna antara kadar monosit yang tinggi pada subjek penelitian dengan kejadian infeksi dibandingkan dengan subjek yang memiliki kadar monosit yang normal pada saat masuk RS. Hal ini sejalan dengan Chamorro dkk bahwa 15\% subjek mengalami infeksi dan menunjukkan peningkatan kadar leukosit, neutrofil, monosit, limfosit, IL-6, dan IL-10 yang meningkat seiring waktu, sementara TNF alfa dan rasio TNF alfa/IL-10 menurun. ${ }^{4}$ Demikian pula Urra dkk, bahwa peningkatan kadar monosit pada hari ke-2 sampai ke-7 awitan stroke berhubungan dengan stroke terkait infeksi. ${ }^{3}$ Monosit merupakan sel imun bawaan multifungsi dengan peran yang sangat penting sekali pada regulasi dari inflamasi dan perbaikan jaringan. Pasien dengan stroke iskemik akut, selnya meningkat di darah, dan menggambarkan perubahan fenotif yang berkurang pada saat ekspresi dari molekul antigen dan rendahnya produksi dari TNF proinflamasi, juga produksi dari anti-inflamasi IL-10 berubah. Perubahan ini penting yang berhubungan dengan risiko infeksi pascastroke. ${ }^{11}$

Penelitian ini menunjukkan kadar prokalsitonin yang tinggi berhubungan secara bermakna dengan kejadian infeksi dibandingkan dengan kadar prokalsitonin yang normal pada saat masuk RS. Prokalsitonin meningkatkan prediksi terjadinya stroke terkait infeksi dibandingkan dengan penanda prognostik kuat yang lainnya. Kombinasi biomarker mungkin lebih baik dari pada pemeriksaan satu biomarker saja sehingga dapat memprediksi terjadinya 
infeksi yang lebih akurat dari awal terjadinya infeksi walaupun klinisnya belum jelas. ${ }^{3}$

Penelitian ini menunjukkan adanya hubungan dengan korelasi negatif antara kadar leukosit dengan luaran fungsional, yaitu semakin tinggi kadar leukosit maka semakin buruk luaran fungsional. Hal ini sejalan dengan Kumar dkk bahwa kadar leukosit yang tinggi pada saat masuk RS berhubungan dengan luaran yang buruk. ${ }^{12}$ Agnihotri dkk mendapatkan hubungan yang signifikan antara kadar leukosit dengan mortalitas serta luaran yang buruk saat pasien pulang. ${ }^{13}$ Peng dkk juga mendapatkan hubungan yang signifikan antara kadar leukosit pada saat masuk RS pada pasien stroke iskemik dengan luaran. ${ }^{1}$ Mekanisme yang menghubungkan kadar leukosit dengan luaran masih belum dimengerti. Buck dkk melaporkan bahwa, pada stroke iskemik akut, peningkatan di awal total leukosit dan neutrofil dikaitkan dengan volume yang besar pada jaringan iskemik awal. ${ }^{14}$

Urra dkk mendapatkan luaran yang buruk berhubungan dengan peningkatan ekspresi Toll-like receptor-4 pada monosit (RO 9,61; IK 95\% 1,27$72,47)$. Terdapat hubungan yang independen antara peningkatan ekspresi TLR4 di monosit dan luaran yang buruk setelah stroke pada manusia, sesuai dengan data eksperimental sebelumnya bahwa pengurangan TLR4 pada tikus yang memiliki infark yang lebih kecil dan kurangnya respons inflamasi setelah iskemik, serta kerusakan otak akibat mekanisme stroke primer melalui signal TLR4. ${ }^{3}$ Pada penelitian ini didapatkan hubungan yang tidak bermakna antara kadar monosit pada stroke akut dengan luaran fungsional.

Penelitian ini menunjukkan terdapat hubungan yang tidak bermakna dengan korelasi negatif antara kadar prokalsitonin pada stroke akut dengan luaran fungsional. Studi Deng dkk, dari 378 pasien stroke, terdapat hubungan yang bermakna secara statistik antara kadar prokalsitonin dengan luaran jangka pendek menggunakan mRS. Prokalsitonin merupakan marker prognostik independen pada luaran fungsional yang buruk (RO 3,45; IK 95\% 2,29-4,77), setelah disetarakan dengan derajat keparahan stroke berdasarkan National Institutes of Health Stroke Scale (NIHSS) dan faktor perancu lainnya pada pasien stroke iskemik. ${ }^{15}$ Fuentes dkk mendapatkan bahwa tingkat prokalsitonin sangat terkait dengan keparahan stroke. Stroke berat berimplikasi dengan luaran yang buruk; itu tidak mengherankan bahwa prokalsitonin juga dikaitkan dengan luaran yang buruk. ${ }^{16}$

Pada penelitian ini pasien stroke akut dengan kadar leukosit tinggi pada saat masuk RS kemungkinan 3,69 kali untuk mengalami terjadi infeksi dibanding pasien dengan kadar leukosit normal. Pasien stroke akut dengan kadar monosit tinggi pada saat masuk RS kemungkinan 2,33 kali untuk mengalami terjadi infeksi dibanding pasien dengan kadar monosit normal. Sedangkan pasien stroke akut dengan kadar prokalsitonin tinggi pada saat masuk rumah sakit kemungkinan 16,50 kali untuk mengalami terjadi infeksi dibanding pasien dengan kadar prokalsitonin normal pada saat masuk rumah sakit.

Hal ini sejalan dengan Chamorro dkk, terdapat $15 \%$ pasien stroke mengalami infeksi disertai peningkatan kadar leukosit, neutrofil, monosit, limfosit, IL-6 dan IL-10 serta penurunan rasio TNFalfa dan TNF-alfa/IL-10. Dengan regresi logistik didapatkan IL-10 (RO:1,08; IK 95\% 1,01-1,16), kadar monosit (RO:1,42; IK 95\% 1,08-1,87); dan skor NIHSS pada saat masuk (RO: 1, 17; IK 95\% 1,05$1,31)$ yang merupakan prediktor independen untuk terjadi infeksi. ${ }^{4}$ Fluri dkk menemukan bahwa dari 383 pasien stroke, $17,2 \%$ berkembang mengalami infeksi didalam 5 hari setelah onset stroke. Dari analisis univariat kadar leukosit yang tinggi pada saat masuk RS 3,35 kali berisiko terjadi infeksi (RO:3,35; IK 95\% 2,14-5,23), monosit (RO:1,43; IK 95\% 1,03-2,00), CRP (RO:1,50; IK 95\% 1,22-1,84), serta prokalsitonin (RO:1,91; IK 95\% 1,38-2,63). ${ }^{7}$

Tingkat awal dari inflamasi dimulai beberapa jam sesudah awitan (onset) iskemik dengan karakteristik munculnya ekspresi adhesi molekul di endotel pembuluh darah dan leukosit di sirkulasi. Leukosit bergerak melewati endotel keluar dari sirkulasi dan penetrasi ke jaringan parenkim otak yang mengakibatkan reaksi inflamasi. ${ }^{17}$ Inflamasi setelah proses iskemik ditandai oleh aktivasi cepat sel mikroglia dan proses infiltrasi dari sel neutrofil serta makrofag pada daerah yang mengalami kerusakan, beberapa mekanisme antara lain second messenger 
yang teraktivasi oleh ion kalsium, peningkatan radikal bebas oksigen dan hipoksia akan mencetuskan beberapa gen proinflamasi melalui beberapa faktor transkripsi. ${ }^{18}$

Mediator inflamasi seperti platelet activating factor, TNF alfa, interleukin-1 $\beta$ dan IL-6 dihasilkan dari sel iskemik. Sebagai akibatnya adalah teraktivasinya adhesion molecule pada endotel seperti ICAM-1, P-selectin, dan E-selectin. Adhesion molecule akan berinteraksi dengan komplemen pada permukaan reseptor sel neutrofil. Proses selanjutnya adalah neutrofil teraktivasi dan melakukan perlekatan pada endotel, menembus dinding pembuluh darah, dan akhirnya menuju pada parenkim otak yang mengalami iskemik. Masuknya neutrofil akan diikuti oleh makrofag dan monosit. Proses inflamasi pascaiskemik akan memperparah kerusakan sel pada saat iskemik melalui beberapa jalur seperti adanya blokade aliran darah oleh neutrofil, mediator toksik yang dihasilkan oleh sel inflamasi.

Reaksi inflamasi juga akan menginduksi sel untuk melakukan kematian sel yang terprogram atau apoptosis. ${ }^{19}$ Walaupun respons awal lokal terhadap kerusakan otak adalah pelepasan mediator-mediator pro-inflamasi yang disertai dengan respons inflamasi sistemik, pasien-pasien dengan lesi di SSP juga menunjukkan adanya tanda-tanda imunodepresi. Hal inilah yang menyebabkan pasien stroke rentan mengalami infeksi. ${ }^{20}$

Penelitian ini memiliki beberapa keterbatasan, yaitu pemeriksaan kadar leukosit, monosit, dan prokalsitonin hanya dilakukan satu kali pada saat pasien masuk rumah sakit saja, sehingga tidak bisa melihat perbandingan kadar leukosit, monosit, dan prokalsitonin pada hari berikutnya. Selain itu penelitian ini tidak menelitihal-hal yang memengaruhi luaran pasien stroke, terutama derajat berat dan lokasi stroke itu sendiri, serta tidak menganalisis hubungan infeksi dengan luaran.

\section{KESIMPULAN}

Terdapat hubungan yang bermakna antara kadar leukosit dan prokalsitonin dengan kejadian infeksi pada stroke akut $(\mathrm{r}=0,315 ; \mathrm{p}=0,020)$ dan $(r=0,604 ; p=0,000)$. Subjek dengan kadar leukosit awal yang normal lebih cenderung untuk tidak mengalami kejadian infeksi sebesar 3,69 kali dibandingkan yang leukositnya tinggi. Demikian pula kadar PCT yang normal di awal cenderung untuk tidak mengalami kejadian infeksi sebesar 16,9 kali dibandingkan subjek dengan PCT tinggi. Kadar leukosit yang tinggi juga berhubungan dengan luaran fungsional yang buruk secara bermakna $(\mathrm{r}=-0,685$ $\mathrm{p}=0,000$ ).

\section{DAFTAR PUSTAKA}

1. Peng Y, Wang D, Zhang J, Xue X, Wang Z, Tomg, W, dkk. Relationship between white blood cell count at admission and short term outcome in patients with acute cerebral infarction. Clin Invest Med. 2011;34(4):249-54.

2. Hallenbeck J, Zoppo G, Jacobs T, Hakim A, Goldman $\mathrm{S}$, Utz U, dkk. Immunomodulation strategies for preventing vascular disease the brain and heart workshop summary. Stroke. 2006;37(12):3035-42.

3. Urra X, Villamor N, Amaro S, Choco MG, Obach $\mathrm{V}$, Oleaga L, dkk. Monocyte subtype predict clinical course and prognosis in human stroke. Journal of Cerebral Blood Flow and Metabolism. 2009;29(5):994-1002.

4. Chamorro A, Amaro S, Vargas M, Obach V, Cervera $\mathrm{A}$, Torres $\mathrm{F}$, dkk. Interleukin 10, monocytes and Increased risk of early infection in ischemic stroke. J Neurol Neurosurg Psychiatry. 2006;77(11):1279-81.

5. Christ-Crain M, Muller B. Procalcitonin in bacterial infections-hype, hope, more or less? Swiss Med Wkly. 2005;135(31-32):451-60.

6. Su L, Han B, Liu C, Liang L, Jiang Z, Deng J, dkk. Value of soluble TREM-1, procalcitonin, and C-reactive protein serum levels as biomarkers for detecting bacteremia among sepsis patients with new fever in intensive care units: a prospective cohort study. BMC Infectious Disease. 2012;12(157):1-10.

7. Fluri F, Morgenthaler NG, Mueller B, Christ-Crain M, Katan M. Copeptin, procalcitonin and routine inflammatory markers-predictors of infection after stroke. Plos One. 2012;7(10):e48309.

8. Westendorp WF, Nederkoom PJ, Vermeij JD, Dijkgraaf MG, Beek D. Post-stroke infection: a systematic review and meta-analysis. BMC Neurol. 2011;11(1):110.

9. Emsley HCA, Tyrrell PJ. Inflammation and infection in clinical stroke. J Cereb Blood Flow and Metab. 2002;22(12):1399-19.

10. Furlan JC, Vergouwen MDI, Fang J, Silver FL. White blood cell count is an independent predictor of outcomes after acute ischaemic stroke. Eur J Neurol. 2014;21(2):215-22. 
11. Chamorro A, Meisel S, Planas AM, Urra X, Van De Beek D, Veltkamp R. The immunology of acute stroke. Nat Rev Neurol. 2012;8(7):401-10.

12. Kumar AD, Boehme AK, Siegler JE, Gillette M, Albright KC, Martin-Schild S. Leukocytosis in patients with neurologic deterioration after acute ischemic stroke is associated with poor outcomes. $\mathrm{J}$ Stroke Cerebrovasc Dis. 2013;22(7):e111-7.

13. Agnihotri S, Czap A, Staff I, Fortunato G, McCulloug LD. Periferal leukocyte counts and outcomes after intracerebral hemorrhage. J Neuroinflammation. 2011:8(1):160-3.

14. Buck BH, Lieberkind DS, Saver JF, Bang Y, Yun SW, Starman S, dkk. Early neutrophilia is associated with volume of ischemic tissue in acute stroke. Stroke AHA. 2008;39(2):355-60.

15. Deng WJ, Shen RL, Li M, Teng JF. Relationship between procalcitonin serum levels and functional outcome in stroke patients. Cell Mol Neurobiol. 2015;35(3):355-61.
16. Fuentes B, Castillo J, Jose BS, Leira R, Serena J, Vivancos J, dkk. The prognostic value of capillary glucose levels in acute stroke. Stroke. 2009:40(1):5628.

17. Misbach J, Lamsudin R, Aliah A, Basyiruddin, Suroto, Alfa AY, dkk. Guideline stroke. Jakarta: Pokdi Stroke, Perdossi; 2011. h. 1.

18. Amantea D, Nappi G, Bernardi G, Bagetta G, Corasaniti MT. Minireview: post-ischemic brain damage: pathophysiology and role of inflammatory mediators. The FEBS Journal. 2008;276(1):13-26.

19. Dirnagl U, Iadecola C, Moskowitz MA. Pathobiology of ischemic stroke: an integrated view. Trends Neurosci. 1999;22(9):391-7.

20. Meisel A, Meisel C, Harms H, Hartman O, Ulm L. Predicting post-stroke infections and outcome with blood-based immune and stress markers. Cerebrovasc Dis. 2012;33(6):580-8. 